Ocean Sci. Discuss., 7, 1953-1976, 2010

www.ocean-sci-discuss.net/7/1953/2010/

doi:10.5194/osd-7-1953-2010

(C) Author(s) 2010. CC Attribution 3.0 License.

\title{
Water masses and zonal current in the Western Tropical Atlantic in October 2007 and January 2008 (AMANDES project)
}

A. C. Silva ${ }^{1}$, M. Grenier ${ }^{2}$, R. Chuchla ${ }^{2}$, J. Grelet $^{3}$, F. Roubaud ${ }^{3}$, B. Hamelin ${ }^{4}$, F. Lyard ${ }^{2}$, and C. Jeandel ${ }^{2}$

${ }^{1}$ Laboratório de Oceanografia Física, Departamento de Oceanografia da Universidade Federal de Pernambuco, Av. Arquitetura s/n, 50740-550, Campus Universitário, Recife, PE, Brazil

${ }^{2}$ Laboratoire d'Etudes en Géophysique et Océanographie Spatiale (LEGOS),

UPS/CNES/CNRS/IRD, Observatoire Midi-Pyrénées, 14 av. E. Belin, 31400 Toulouse, France ${ }^{3}$ US IMAGO, IRD Brest, 29240 Plouzané, France

${ }^{4}$ CEREGE (CNRS/Univ Paul Cezane) Technopôle de l'Arbois, Aix en Provence, France

Received: 16 October 2010 - Accepted: 10 November 2010 - Published: 30 November 2010 Correspondence to: A. C. Silva (alex.csilva@ufpe.br)

Published by Copernicus Publications on behalf of the European Geosciences Union.

Water masses and zonal current in the

Western Tropical

Atlantic

A. C. Silva et al.

\section{Title Page}

Abstract

Conclusions

Tables

14

4

Back

Full Screen / Esc

Printer-friendly Version

Interactive Discussion
Figures

$\rightarrow 1$

Close 


\section{Abstract}

The properties and circulation of water masses are examined using data collected from a hydrographic and Acoustic Doppler Current profiler in the Western Tropical Atlantic during two cruises of the GEOTRACES process study "AMANDES" (AMazon5 ANDEans): AMANDES I (October-November 2007) and AMANDES II (January 2008). In the upper layer (from the sea surface to $150 \mathrm{~m}$ ) means of vertical sections of velocity are showing the structure of the Current (NBC) and North Equatorial Countercurrent. In the lower layer (below $150 \mathrm{~m}$ ) the subsurface velocity core of the North Brazil UnderCurrent, Western Boundary Undercurrent (WBUC) and northern branch of the 10 South Equatorial Current (nSEC) could be observed. In October the WBUC flows southeastward with a velocity of about $0.3 \mathrm{~m} \mathrm{~s}^{-1}$. In the studied area during October 2007, the NBUC and nSEC are transporting South Atlantic Central Water (SACW) from the Southern Hemisphere whereas the WBUC transports North Atlantic Central Water (NACW) southeastward. In the deep layers, the North Atlantic Deep Water (NADW)

15 is composed of three components: the Upper North Atlantic Deep Water - UNADW (between 1310 and 1650 m), the Middle North Atlantic Deep Water (between 1930 and $2400 \mathrm{~m}$ ), the Lower North Atlantic Deep Water (centered around $3430 \mathrm{~m}$ ).

Off Guyana, the Antartic Intermediate Water (AAIW) changes of composition between October 2007 (45.2\% ACW, 32.2\% AAIW source $_{\text {and } 22.6 \%}$ UNADW) and January 2008 (62.4\% ACW, 23.5\% AAIW source and 14.1\% UNADW).

These intermediate waters are significantly warmer, less oxygenated and saltier than their southern source, reflecting both oxygen consumption and mixing with the Atlantic Central Water (ACW) and the Upper North Atlantic Deep Water during their northward transit.

\section{OSD}

7, 1953-1976, 2010

Water masses and zonal current in the Western Tropical Atlantic

A. C. Silva et al.

\section{Title Page}




\section{Introduction}

The ocean dynamic of the coastal system of the NE shelf of South America is extremely complex. This system comprises the Amazon's shelf and estuary as well as the French Guyana shelf. Wind stress is essentially due to the Trade Winds; other forcings are due 5 to the enormous fresh water discharge (averages $180000 \mathrm{~m}^{3} \mathrm{~s}^{-1}$ ) and sediment load $\left(1.1-1.3 \times 10^{9}\right.$ tons $\mathrm{y}^{-1}$ ) as well as strong tidal currents (Oltman, 1968; Meade et al., 1985; Geyer et al., 1996). The coastal system is connected to the tropical Atlantic Ocean through complex Western Boundary circulation.

The southwest tropical Atlantic Ocean plays an important role in the inter10 hemispheric changes of mass, heat and salt (Schmitz and Mc Cartney, 1993; Dengler et al., 2004). Along the western boundary, whereas the Deep Western Boundary Current transports cold North Atlantic Deep Water towards the Southern Hemisphere, the North Brazil Current/North Brazil UnderCurrent system (hereafter NBC/NBUC) transports warm surface waters northward from the Southern Hemisphere. Those are the 15 most active currents at the western frontier area, mainly composed of waters from the Equatorial and South Atlantic, originating from the forking of the South Equatorial Current (SEC), with a northeast flow along the north Brazilian coast. These current systems are a major component of the global meridional overtuning circulation - MOC (Gordon, 1986; Schott et al., 2005).

20 These eastward currents may also be fed by North Atlantic waters through the recirculation of the North Equatorial Current (NEC) and the Western Boundary Undercurrent, but a direct connection between the WBUC and the NEUC/EUC is still unclear (Schott and Böning, 1991; Wilson et al., 1994; Bourlès et al., 1999a, b). Actually, the complete seasonal and spatial comprehension of the WBUC circulation in the region is 25 not clearly defined yet.

Crossing the equator, part of the NBC/NBUC is retroflected eastward into the Equatorial UnderCurrent (EUC), while another portion of the NBC continues northwestward and is retroflected again near $7^{\circ} \mathrm{N}-50^{\circ} \mathrm{W}$ into the North Equatorial Counter Current
OSD

7, 1953-1976, 2010

Water masses and zonal current in the

Western Tropical

Atlantic

A. C. Silva et al.

\section{Title Page}


(NECC; Johns et al., 1998; Bourlès et al., 1999a, b).

These retroflections cause the formation of rings (Didden and Schott, 1993; Johns et al., 1990; Richardson et al., 1994). Satellite images and in situ observations demonstrate that these rings break away from the retroflection and move northwestward along 5 the coast of Guyana, representing one of the main process transporting surface waters from the equatorial and southern Atlantic toward the Northern Hemisphere as part of the Meridional Overtuning Circulation (Johns, et al., 2003; Garzoli et al., 2003).

Despite recent advances on the knowledge about all the mechanisms mentioned above, the meridional distribution and blending of the water masses converging to 10 this dynamical ocean area have been poorly investigated so far. Metcalf and Stalcup (1967), Cochrane et al. (1979), Wilson et al. (1994), Bourlès et al. (1999a,b) and Goes et al. (2005) identified three different origins for the water masses encountered in the upper layers of the western equatorial Atlantic. The first was named the North Atlantic Water (NAW), originating from the subtropical region of the Northern Hemisphere, be15 ing advected towards the equator by the NEC, and characterized by high salinities above the thermocline and low $\mathrm{O}_{2}$ concentrations below the thermocline. The second was named the South Atlantic Water (SAW), exhibiting high salinity values above the thermocline and low salinity values and high $\mathrm{O}_{2}$ concentrations below the thermocline, when compared with the NAW. The SAW is carried to the studied coastal system by the NBC/NBUC system. The third water mass is identified as the Eastern Tropical Atlantic Water (EAW), advected via the southern edge of the NEC and the northern branch of the South Equatorial Current (SEC) and characterized by the lowest $\mathrm{O}_{2}$ concentrations around the thermocline when compared to the SAW and NAW.

The aim of the present work is to investigate the spatial and seasonal variability of the water masses along the northern coast of Brazil, using hydrographic data $\left(\mathrm{CTDO}_{2}\right)$ and acoustic Doppler current profiler (ADCP) observations collected during two short oceanographic cruises, AMANDES I and II. A particular attention is given to the sea area comprised between the northern continental shelf and the $4000 \mathrm{~m}$ isobath, a region marked by the strong ocean dynamics associated to Amazon River discharges
OSD

7, 1953-1976, 2010

Water masses and zonal current in the Western Tropical Atlantic

A. C. Silva et al.

Title Page

Abstract Introduction

Conclusions

Tables

References Figures

14

4

Back

Close

Printer-friendly Version

Interactive Discussion 
and by the confluence of water masses coming from the North Atlantic and the South Atlantic.

\section{Data and methodology}

\subsection{Study area and data collection}

5 The hydrographic data sets (Fig. $1-\mathrm{CTDO}_{2}$ stations) were collected using the R/V Antea cruises, as part of the AMANDES project. The general objective of this GEOTRACES' process study is to better understand and quantify the land to ocean physical and chemical fluxes, including geochemical tracers. AMANDES focuses in particular on the physico-chemical exchange between the passive margin of the Amazon River 10 estuary, characterized by an important continental influx, and its significant impact on neighboring Atlantic ocean water masses.

Data used in this work were sampled during the late boreal Fall (17-31 October 2007) - AMANDES 1 and boreal Winter (11-26 January 2008) - AMANDES 2 in the region bounded by the $4^{\circ} \mathrm{N}$ and $8^{\circ} \mathrm{N}$, between $47.5^{\circ} \mathrm{W}$ and $51.5^{\circ} \mathrm{W}$ (Fig. 1). Sea 15 data correspond to continuous vertical profiles of temperature, salinity and oxygen $\left(\mathrm{CTDO}_{2}\right)$ obtained using a Sea Bird Electronics SBE911plusCTD, with high resolution sensors for Conductivity measurement (resolution $=0.0003 \mathrm{~s} \mathrm{~m}^{-1}$ ), Temperature (resolution $\left.=0.0002^{\circ} \mathrm{C}\right)$, Oxygen $\left(0.02 \mathrm{mll}^{-1}\right)$ and Pressure (resolution=0.068 dbar). Measurements of the oxygen sensor are calibrated by comparing the results of the chem-

ical analyses of waters (determined using a Winkler method) collected with 12-bottle Rosette and the measurements of the probe obtained at the same pressure. Comparison with the rosette-CTD system and occasional salinity determinations of pumped water on an Autosal salinometer indicated that the data are reliable to at least $.01^{\circ} \mathrm{C}$ in temperature and .01 in salinity.

25 Shipboard ADCP observations were collected continuously along the track lines during both cruises. The R/V Antea is equipped with a $75 \mathrm{kHz}$ Ocean Surveyor, lowered
OSD

7, 1953-1976, 2010

Water masses and zonal current in the

Western Tropical

Atlantic

A. C. Silva et al.

Title Page

Abstract

Introduction

Conclusions

References

Tables

Figures

14

$>1$

4

Back

Close

Full Screen / Esc

Printer-friendly Version

Interactive Discussion 
into the ship's well. Data were collected with a vertical depth cell (bin) length of $16 \mathrm{~m}$. The profiling range was $500-750 \mathrm{~m}$ depending on the sea state.

\section{Results and discussion}

\subsection{The zonal current system in the region}

5 Means of vertical velocity sections are showing the structures of the NBC, NBUC, WBUC, NECC and nSEC currents. During October 2007, along the transect \#1, a current flowing eastwards at 5.7-5.8 $\mathrm{N}$ and advecting waters from the Southern Hemisphere (the nSEC) is observed up to the subsurface ( $200 \mathrm{~m}$ depth). The core of the NECC is centered around $50 \mathrm{~m}$ depth, displaying a maximum velocity of about $101.3 \mathrm{~m} \mathrm{~s}^{-1}$, located at $6.6^{\circ} \mathrm{N}$ (Fig. 2a). This observation is consistent with those of Bourlès et al. (1999a) who observed in summer the core of the NECC centered around $60-80 \mathrm{~m}$ depth, with maximum velocities of about $1.0-1.2 \mathrm{~m} \mathrm{~s}^{-1}$.

In the same period, along the transect $\# 2$ at $5^{\circ} \mathrm{N}-51^{\circ} \mathrm{W}$ a portion of the NBC flowing continuously northwestward along the coast is observed (Fig. 2b), suggesting that another portion of the NBC separates sharply from the coast to feed the NECC. Below the NBC the subsurface velocity core of the NBUC is located around $250 \mathrm{~m}$, with maximum velocities above $1 \mathrm{~m} \mathrm{~s}^{-1}$. The WBUC is flowing southeastward along the boundary between $5.6-5.9^{\circ} \mathrm{N}$, around $150-350 \mathrm{~m}$ depth (Fig. $2 \mathrm{~b}$ ). This current also displays a weak velocity $\left(0.3 \mathrm{~m} \mathrm{~s}^{-1}\right)$, but in the opposed direction to that of the NBUC. Colin and Bourlès 20 (1994) have localized the WBUC slightly deeper $(250-800 \mathrm{~m})$, but with similar velocities of about $0.3 \mathrm{~m} \mathrm{~s}^{-1}$ in February and June. The same authors observed that during late winter, spring and beginning of summer, the WBUC was trapped along the upper part of the slope and flowing southeastward.

The current flowing westward along the same transect is the continuity of the nSEC. 25 North of $6.6^{\circ} \mathrm{N}$, currents flowing eastward are probably corresponding to the NECC with maximum velocity core of about $0.5 \mathrm{~m} \mathrm{~s}^{-1}$ at $150 \mathrm{~m}$ depth, weaker than the current
OSD

7, 1953-1976, 2010

Water masses and zonal current in the

Western Tropical

Atlantic

A. C. Silva et al.

\section{Title Page}

\section{Full Screen / Esc}

Printer-friendly Version

Interactive Discussion 
observed in the region of transect 1 during the same period (Fig. 2b). These observations are also confirmed by water mass transports described in the Sect. 3.2.

In January 2008 (data not shown) ADCP data allow identifying the NBC near the surface, with a maximum velocity larger than in October $\left(\sim 0.7 \mathrm{~m} \mathrm{~s}^{-1}\right)$ between $5.7^{\circ} \mathrm{N}-$

$56.12^{\circ} \mathrm{N}$, but these data do not allow distinguishing clearly NBUC, NECC or WBUC. This could result either from mesoscale eddies or from tidal forcing (internal waves). These points will be discussed in a further study.

\subsection{Water masses analysis}

\subsubsection{Surface water layer $(<400 \mathrm{~m})$}

\section{October-November 2007 (Amandes I)}

Surface waters with low salinity values (Table 1, Fig. 3a), observed at the coastal stations in October 2007 (station 1-4), are reflecting the influence of South America river discharges (e.g., the Amazon) and of tropical rains. The NBC retroflexion induces that Amazon fresh waters influence is predominating in large areas off the Amazon shelf 15 as observed at stations $1-5$ and $1-7$. The salinity maximum corresponding to densities higher than $25.0 \mathrm{~kg} \mathrm{~m}^{-3}$ represent the Salinity Maximum Water (SMW), part of the Tropical Surface Waters (TSW) (Stramma et al., 2005; Fig. 3a).

The Atlantic Central Waters are flowing between the thermocline and the isopycnal $\sigma_{\theta}=27.1 \mathrm{~kg} \mathrm{~m}-3$ (around $450 \mathrm{~m}$ depth), their core being at $\sigma_{\theta}=26.7 \mathrm{~kg} \mathrm{~m}-3$. These waters are characterized by a nearly linear $\theta$-S diagram (Fig. 3a). Silva et al. (2009) describe the penetration of cores of maximum salinity $(\geq 36.6)$ located around $100-$ $150 \mathrm{~m}$ depth originating in the Southern Hemisphere and flowing towards the Northern Hemisphere through the NBC/NBUC system in the studied area.

At stations 1-5 and 1-7 (Fig. 3a and b), the North Atlantic Central Water (NACW) 25 is characterized by high salinity values above and below the thermocline associated with relatively high $\mathrm{O}_{2}$ concentrations (Bourlès et al., 1999a; Stramma et al., 2005).
OSD

7, 1953-1976, 2010

Water masses and zonal current in the

Western Tropical

Atlantic

A. C. Silva et al.

Title Page

Abstract Introduction

Conclusions

References

Tables Figures

14

4

Back

Close Full Screen / Esc

Printer-friendly Version

Interactive Discussion

$>$ I

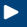

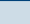


The NACW is also occurring at station 1-4, but slightly mixed with waters of lower salinity. Contrastingly, lower salinities and high $\mathrm{O}_{2}$ concentrations at station 1-6 reveal the occurrence of the South Atlantic Central Water (SACW), flowing at the same depths as the NACW (Fig. 3a and b). At this station, the southern waters observed are likely 5 carried by westward flows of the nSEC.

At the northern stations (1-5 and 1-7), the occurrence of the NACW is likely due to a stronger NECC in October-November. The NECC at this location receives a contribution of waters from the north carried by the NEC. Indeed, Garzoli et al. (2004) and Bourlès et al. (1999a) describe that a retroflected portion of the Atlantic NEC could be entrained into the NECC, fact confirmed here by our data.

Mixture of waters of northern and southern origins, enhanced by the two currents flowing in opposite direction (NBUC and WBUC, Fig. 2) are likely explaining the lower salinities characterizing station 1-4 (Fig. 3a).

\section{Januray 2008 (Amandes II)}

15 During AMANDES II at station 2-31 and at station 2-9 (both $\sigma_{\theta}>26 \mathrm{~kg} \mathrm{~m}^{-3}$ ), the salinity maximum is associated to low $\mathrm{O}_{2}$ concentrations that are characterizing the NACW in subsurface (Fig. $3 c$ and d).

At station 2-9, rapid $\mathrm{O}_{2}$ concentration decreases and salinity increases between $19.5^{\circ} \mathrm{C}$ and $21^{\circ} \mathrm{C}$ could reveal the intrusion of NACW, precluding a southern origin for 20 these salty waters. From $\sigma_{\theta}=26.0 \mathrm{~kg} \mathrm{~m}^{-3}$ to $\sigma_{\theta}=27.0 \mathrm{~kg} \mathrm{~m}^{-3}$, the linear $\theta-\mathrm{S}$ (Fig. 3c) corresponds to the NACW. The NACW are observed at station 2-9 below $150 \mathrm{~m}$ depth (Fig. 3c and d).

Potential Temperature-Salinity diagram $(\theta-S)$ and Potential Temperature-Oxygen $(\theta-$ $\mathrm{O}_{2}$ ) diagrams also reveal the NACW occurrence at stations 2-7, 2-8 and 2-13 along 25 the isotherm $20^{\circ} \mathrm{C}$. In this region the presence of waters transported southeastward from the Northern Hemisphere was observed (Fig. 2).
OSD

7, 1953-1976, 2010

Water masses and zonal current in the Western Tropical Atlantic

A. C. Silva et al.

\section{Title Page}

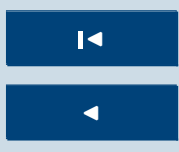

\section{Full Screen / Esc}

Printer-friendly Version

Interactive Discussion 


\subsubsection{Intermediate water layer (400-1200 m)}

Intermediate layers being less disturbed by currents and various contributions, the water masses are characterized by curved profiles of potential temperature - salinity ( $\theta-S$; Fig. 4a) and potential temperature - dissolved oxygen ( $\theta-\mathrm{O}_{2}$; Fig. 4b).

\section{October-November 2007 (AMANDES I)}

During boreal fall, a mixture of water masses is observed below $400 \mathrm{~m}$ (about $8-7^{\circ} \mathrm{C}$ ) at station 1-6, characterized by an increase of oxygen concentration associated to a decrease of salinity values at this depth (Fig. $4 a$ and b). In the same region, Goest et al. (2005) identified the EAW, with an increase of oxygen concentration at the same 10 depth (about $8^{\circ} \mathrm{C}$ ). The EAW is carried to the studied area by northern edge of the SEC (Fig. 2).

The salinity minimum corresponds to $T=5.09^{\circ} \mathrm{C}$ (Fig. 4a and Table 1), typical for the Antartic Intermediate Water (AAIW). Formed at the sub-surface in the Subantartic Front region, AAIW spreads along the western boundary and crosses the equatorial zone with the North Brazil UnderCurrent (NBUC). This water mass is a priori characterized by low salinity and high oxygen concentration (Oudot et al., 1998; Tsuchiya et al., 1994). However, the $\theta-\mathrm{O}_{2}$ profile shows low oxygen concentrations (about $140 \mu \mathrm{mol} \mathrm{kg}^{-1}$ ) for this water, reflecting that oxygen depletion occurred during its transport from the austral ocean, which could be biological, or due to mixture of waters, or both (Fig. 4b). This water mass will be designed as "AAIW-Guyane" in the following.

\section{January 2008 (AMANDES II)}

As in October, AAIW-Guyanne (low $S$, low $\mathrm{O}_{2}, T \sim 5^{\circ} \mathrm{C}$, Fig. 4 d) was observed during winter.

Causes of the $\mathrm{O}_{2}$ depletion affecting this water layer are discussed in Sect. 3.3.

OSD

7, 1953-1976, 2010

Water masses and zonal current in the Western Tropical Atlantic

A. C. Silva et al.

\section{Title Page}

\section{Full Screen / Esc}

Printer-friendly Version

Interactive Discussion 


\subsubsection{Deep water layer $(1200-4000 \mathrm{~m})$}

The North Atlantic Deep Water (NADW) was observed during October 2007 (Fig. 4c and d) and January 2008 (Fig. 5a and b). The NADW is warm, salty, highly oxygenated and poor in nutrients (Tsuchiya et al., 1994; Oudot et al., 1998) and flows southward 5 primarily by the Deep Western Boundary Current (DWBC). The NADW is composed of three components (Oudot et al., 1998; Ahran et al., 1998) (Fig. 4c and d and Table 1). In October, stations were deep enough to allow the observation of the three layers whereas only two could be sampled in Januray (Figs. 4 and 5).

- the Upper North Atlantic Deep Water (UNADW), characterized by a salinity maximum due to the intrusion of the Mediterranean Sea observed between 1550 and $1650 \mathrm{~m}$ in October and slightly higher in January (1310-1450 m);

- the Middle North Atlantic Deep Water (MNADW) originating in the Labrador Sea and characterized by a $\mathrm{O}_{2}$ maximum (here, $254-261 \mu \mathrm{mol} \mathrm{kg}^{-1}$ ) and flowing just below the minimum concentration of nutrients between 1930 and $2400 \mathrm{~m}$ in October and 2050 and $2300 \mathrm{~m}$ in January;

- the Lower North Atlantic Deep Water (LNADW), that primarily results from the convection in the Arctic Seas. The LNADW displays an $\mathrm{O}_{2}$ maximum, is less salty but colder therefore more dense than the two other components. At $7^{\circ} \mathrm{N} 49.8^{\circ} \mathrm{W}$ (station 1-5), the LNADW core is located at $3430 \mathrm{~m}$.

20 According to Tsuchiya et al. (1994), the minimum of oxygen concentrations observed between the MNADW and the LNADW could be attributed to the influence of the Upper Circumpolar Deep Water (UCDW).

\subsection{AAIW-Guyana}

AAIW off the French Guyana coast (AAIW-Guyana) is oxygen poor whereas this wa-

ter mass is oxygen saturated in its formation zone. Two processes are susceptible to

OSD

7, 1953-1976, 2010

Water masses and zonal current in the

Western Tropical

Atlantic

A. C. Silva et al.

\section{Title Page}

Abstract

Introduction

Conclusions

References

Tables

Figures

14

4

Back

Close

Printer-friendly Version

Interactive Discussion 
consume oxygen during the transit between the Sub Antarctic Front and the AMANDES zone: bacterial respiration during the remineralization of organic material and/or mixing with water masses already oxygen depleted. In order to quantify the bacterial consumption impact within the core of AAIW, we used the Apparent Oxygen Utilization 5 parameter (AOU). AOU is defined as the difference between the supposed initial oxygen content of the water mass (deduced from its potential temperature) and the oxygen value measured at the sampling site and time (Fig. 7, AOU $=\mathrm{O}_{2}$ sat $-\mathrm{O}_{2 m}$ ).

Parameters of the AAIW-Guyana are:

$$
\theta_{\mathrm{m}}=5.09^{\circ} \mathrm{C}, S_{\mathrm{m}}=34.56, \mathrm{O}_{2 \mathrm{~m}}=140 \mu \mathrm{mol} \mathrm{kg}{ }^{-1}
$$

10 Based on its potential temperature, the dissolved oxygen content at saturation for this water mass should be $\mathrm{O}_{2 \text {,sat }}=307 \mu \mathrm{mol} \mathrm{kg}^{-1}$. Subtracting the above $\mathrm{O}_{2 \mathrm{~m}}$ value yields and AOU of $167 \mu \mathrm{mol} \mathrm{kg}{ }^{-1}$.

AAIW $_{\mathrm{S}}$ is subducting in the Sub Antarctic front $\left(\sim 32.5^{\circ} \mathrm{W} 46.9^{\circ} \mathrm{S}\right)$, where its is characterized by the following "source" parameters (subscript s): $\theta_{\mathrm{s}}=3.61^{\circ} \mathrm{C}, S_{\mathrm{s}}=34.168$ 15 and $\mathrm{O}_{2, \mathrm{~s}}=322 \mathrm{\mu mol} \mathrm{kg}^{-1}$ (e-WOCE atlas http://odv.awi.de/).

Assuming that the oxygen content of $\mathrm{AAIW}_{s}$ had only been consumed by biology, AOU of the AAIW-Guyana should be equal to $322-140=182 \mu \mathrm{mol} \mathrm{kg}{ }^{-1}$. However, AOU values along a section of the south-west Atlantic $(\sim 150 \mu \mathrm{mol} / \mathrm{l}$, e-WOCE atlas http://odv.awi.de/) for the same water mass and latitude are generally smaller than that estimated here. In other words, AAIW-Guyane is warmer, less oxygenated and saltier than AAIW $_{s}$ arriving from its source and having experienced only oxygen consumption during its transit (Fig. 8). These results suggest that AAIWs experienced mixing with other water masses before reaching the studied area.

The warmer temperature and lower oxygen suggest a mixture with the Atlantic Central Waters $(A C W)$ whereas salinity content likely reflects an influence of the Upper North Atlantic Deep Water (UNADW).

Mixing proportions were estimated using the hydrological properties for ACW and UNADW end-members reported in Table 1 and Fig. $4 \mathrm{c}$ and $\mathrm{d}$ and the following
OSD

7, 1953-1976, 2010

Water masses and zonal current in the

Western Tropical

Atlantic

A. C. Silva et al.

\section{Title Page}

Abstract 
equations:

$M_{\mathrm{m}}=\alpha M_{1}+\beta M_{2}+\gamma M_{3}$

OSD

$S_{m}=\alpha S_{1}+\beta S_{2}+\gamma S_{3}$

$\theta_{m}=\alpha \theta_{1}+\beta \theta_{2}+\gamma \theta_{3}$

${ }_{5} \alpha+\beta+\gamma=1$

Where:

$\mathrm{M}$ is the water mass, $S$ and $\theta$ are its physical parameters

$\alpha, \beta$ and $\gamma$ are the mixing coefficients

$m$ is the water mass to be characterized

101 refers to the ACW, 2 to the AAIW - source and 3 to the UNADW.

Based on these data, we obtained a mixture composed of $45.2 \%$ ACW, $32.2 \%$ AAIWs and 22.6\% UNADW for AAIW-Guyana measured October 2007, and a mixture composed of $62.4 \%$ ACW, $23.5 \%$ AAIWs and $14.1 \%$ UNADW for AAIW-Guyana measured in January 2008. Such differences underline that seasonal forcing are sig15 nificantly impacting the composition of waters, down to intermediate levels. Maamaatuaiahutapu et al. (1994) also observed seasonal variations of the AAIW composition in the region of Brazil-Malvinas confluence, though less pronounced $(84.5 \%$ AAIW in spring, and $88.6 \%$ AAIW in winter). Mechanisms yielding to these differences will be discussed in a further study.

\section{Summary and conclusions}

Observations collected during two cruises carried out at different periods of the year (October 2007 and January 2008) contributed to the comprehension of the water masses and zonal currents in the Western Tropical Atlantic.

Water masses and zonal current in the

Western Tropical

Atlantic

A. C. Silva et al.

Title Page 
In October 2007, shipboard ADCP data showed the structures of the NBC, NBUC, WBUC, NECC and nSEC. Upper level mean currents were flowing northwestward along the shelf break and the NBC was outcropping at the surface. Its low velocity $\left(0.2 \mathrm{~m} \mathrm{~s}^{-1}\right)$ suggested that a significant fraction left the coast to feed the NECC, the 5 remaining fraction keeping flowing northwestward along the shelf. Below the NBC, the subsurface velocity core of the NBUC flowed in the same direction with a maximum velocity $\left(>1 \mathrm{~m} \mathrm{~s}^{-1}\right)$, whereas a southeastward undercurrent -corresponding to the WBUChas been observed along the boundary, with maximum velocity core of about $0.3 \mathrm{~m} \mathrm{~s}^{-1}$. At $6.0^{\circ}-7.5^{\circ} \mathrm{N}$ the eastward flow of the NECC is observed with maximum velocity core $10\left(>1 \mathrm{~m} \mathrm{~s}^{-1}\right)$ centered around $60-80 \mathrm{~m}$ whereas south of it only a small fraction of the nSEC has been observed. At the same season, surface waters with low salinity values reflecting the influence of the Amazon fresh waters were observed off the Amazon shelf, extending offshore within the retroflection of the NBC/NECC system. In January 2008 ADCP data collected over the continental slope, allow identifying NBC near 15 the surface, but do not allow distinguishing clearly NBUC or WBUC. This could result either from mesoscale eddies or from tidal forcing (internal waves), and need further investigation.

The linear $\theta$-S relationship observed in the thermocline characterizes the Atlantic Central Waters (ACW). Its North Atlantic component (NACW, salty and oxygen rich) is advected by WBUC/NECC. Contrastingly, South Atlantic Central Waters (SACW, low in oxygen) are transported from the Southern Hemisphere by NBUC and nSEC.

During its transports from Antarctic, AAIW is submitted to both oxygen consumption and water mass mixing, probably with the ACW and the Upper North Atlantic Deep Water (UNADW). AAIW off Guyana are warmer, saltier and less oxygenated in winter than in fall, because of the larger proportion of its ACW end-member $(62.4 \%$ instead of $45.2 \%)$.

Below these depths, North Atlantic Deep Water (NADW) is found. At $1500 \mathrm{~m}$ flows the UNADW, characterized by its maximum salinity $(S=35)$ due to an intrusion of the Mediterranean Sea. Then, the Middle NADW is observed around $2000 \mathrm{~m}$, with
OSD

7, 1953-1976, 2010

Water masses and zonal current in the Western Tropical Atlantic

A. C. Silva et al.

\section{Title Page}


maximum oxygen concentration (255-260 $\left.\mu \mathrm{mol} \mathrm{kg}^{-1}\right)$. A second maximum of oxygen concentration around $3500 \mathrm{~m}$ illustrates the Lower NADW, less salty and colder than the two previous currents.

Acknowledgements. The authors thank the captain and crews of the R/V Antea, Francois Bau5 rand, Claudie Marec, Lionel Scouarnec, Lionel Fichen, as well as the whole DT INSU and US IMAGO teams for their professional technical support. Discussions with Bernad Bourlès helped improving this manuscript. Funds supporting AMANDES GEOTRACES process study are provided by ANR-Blanc (NT05-3_43160- AMANDES), CNRS-INSU/LEFE, CNRS-INSU/DT and IRD.

Arhan, M., Mercier, H., Bourlès, B., and Gouriou, Y.: Hydrographic sections across the Atlantic at $7^{\circ} 30 \mathrm{~N}$ and $4^{\circ} 30 \mathrm{~S}$, Deep-Sea Res., 45, 829-872, 1998.

Bourlès, B., Molinari, R. L., Johns, E., Wilson, W. D., and Leaman, K. D.: Upper layer currents in the western tropical North Atlantic (1989-1991), J. Geophys. Res., 104, 1361-1375, 1999a.

Bourlès, B., Gouriou, Y., and Chuchla, R.: On the circulation in the upper layer of the western equatorial Atlantic, J. Geophys. Res., 104, 21151-21170, $1999 \mathrm{~b}$.

Cochrane, J. D., Kelly, F. J., and Olling, C. R.: Subtermocline countercurrents in the western equatorial Atlantic Ocean, J. Phys. Oceanogr., 9, 724-738, 1979.

Colin, C. and Bourlès, B.: Western boundary currents and transports off French Guiana as inferred from Pegasus observations, Oceanologica Acta, 17, 143-157, 1994.

Dengler, M., Schott, F. A., Eden, C., Brandt, P., Fischer, J., and Zantopp, R. J.: Break- up of the Atlantic deep western boundary current into eddies at 81S, Nature, 432, 1018-1020, 2004.

Didden, N. and Schott, F.: Eddies in the North Brazil Current retroflection region observed by Geosat altimetry, J. Geophys. Res., 98, 20121-20131, 1993.

25 Garzoli, S. L., Ffield, A., and Yao, Q.: NBC retroflection and rings, in Interhemispheric Water Exchanger in the Atlantic Ocean, Elsev. Oceanogr. Serie, 68, 357-374, (ISBN 0-444-512675), 2003.

Garzoli, S. L., Ffield, A., Johns, W. E., and Yao, Q.: North Brazil Current retroflection and transports, J. Geophys. Res., 109, CO1013, doi:10.1029/2003JC001774, 2004.
OSD

7, 1953-1976, 2010

Water masses and zonal current in the

Western Tropical

Atlantic

A. C. Silva et al.

\section{Title Page}

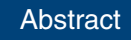

Introduction

Conclusions

References

Tables

Figures

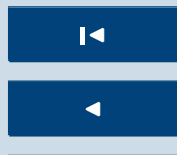

Back

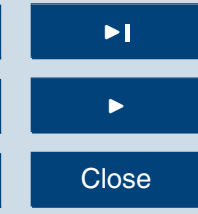

Full Screen / Esc

Printer-friendly Version

Interactive Discussion 
Geyer, W. R., Beardsley, R. C., Lentz, S. J., Candela, J., Limeburner, R., Johns, W. E., Castro, B. M., and Soares I. D.: Physical oceanography of the Amazon Shelf, Cont. Shelf Res., 16, 575-616, 1996.

Goes, M., Molinari, R., da Silveira, I., and Wainer, I.: Retroflection of the North Brazil Current during February 2002, Deep-Sea Res., 52, 647-667, 2005.

Gordon, A. L.: Interocean exchanger of thermocline water, J. Geophys. Res., 91, 5037-5046, 1986.

Johns, W. E., Lee, T. N., Schott, F. A., Zantopp, R. J., and Evans, R. H.: The North Brazil Current retroflection: seasonal structure and eddy variability, J. Geophys. Res., 95(C12), 22103-22120, 1990.

Johns, W. E., Beardsley, R. C., Candela, J., Limeburner, R., and Castro, B.: Annual cycle and variability of the North Brazil Current, J. Phys. Oceanogr., 28, 103-128, 1998.

Johns, W. E., Zantopp, R. J., and Goni, G. J.: Cross-gyre watermass transport by North Brazil Current Rings, edited by: Goni, G. J. and Malanotte-Rizzoli, P., Interhemispheric Water Exchanger in the Atlantic Ocean, Elsev. Oceanogr. Ser., 68, 411-441, (ISBN 0-444-51267-5), 2003.

Maamaatuaiahutapu, K., Garcon, V. C., Provost, C., Boulahdid, M., and Osiroff, A. P.: Spring and winter water mass composition in the Brazil-Malvinas Confluence, J. Mar. Res., 52, 397-426, 1994.

20 Meade, R. H., Dunne, T., and Richey, J. E.: Storage and remobilization of suspended sediment in the lower Amazon River of Brazil, Science, 228, 488-490, 1985.

Metcalf, W. and Stalcup, M. C.: Origin of the Atlantic Equatorial Undercurrent, J. Geophys. Res., 72, 4959-4975, 1967.

Oltman, R. E.: Reconaissance investigation of discharge and water quality of the Amazon River. US, Geological Survey, Circular 552, Washigton D.C, 16 pp., 1968.

Oudot, C., Morin, P., Baurand, F., Wafar, M., and Le Corre, P.: Northern and southern water masses in the equatorial Atlantic: distribution of nutrients on the WOCE A6 and A7 lines, Deep Sea Res., 873-902, 1998.

Richardson P. L., Hufford, G., Limeburner, R., and Brown, W.: North Brazil Current retroflection eddies, J. Geophys. Res., 99, 5081-5093, 1994

Schmitz, W. J. and Mccartney, M. S.: On the North Atlantic circulation, Rev. Geophys., 31(1), 29-49, 1993.

Schott, F. A. and Böning, C. W.: The WOCE model in the western equatorial Atlantic: Upper
OSD

7, 1953-1976, 2010

Water masses and zonal current in the

Western Tropical

Atlantic

A. C. Silva et al.

Title Page

Abstract

Introduction

Conclusions

References

Tables

Figures

14

$\rightarrow 1$

4

Back

Close

Printer-friendly Version

Interactive Discussion 
layer circulation, J. Geophys. Res., 96, 6993-7004, 1991.

Schott, F. A., Dengler, M., Zantopp, R., Stramma, L., Fischer J., and Brandt, P.: The shallow and deep western boundary circulation of the South Atlantic at $5-11^{\circ} \mathrm{S}$, J. Phys. Oceanogr., 35, 2031-2053, 2005.

5 Silva, A. C., Bourlès, B., and Araujo, M.: Circulation of the thermocline salinity maximum waters off the northern Brazil as inferred from in situ measurements and numerical results, Ann. Geophys., 27, 1861-1873, 2009, http://www.ann-geophys.net/27/1861/2009/.

Stramma, L., Rhein, M., Brandt, P., Dengler, M., Boning, C., and Walter, M.: Upper ocean circulation in the western tropical Atlantic in boreal fall 2000, Deep-Sea Res., 52, 221-240, 2005.

Tsuchiya, M., Talley, L. D., and McCartney M. S.: Water-mass distributions in the western South Atlantic; A section from South Georgia Island (54S) northward across the equator, J. Marine Res., 52, 55-81, 1994.

Wilson, W. D., Johns, E., and Molinari, R. L.: Upper layer circulation in the western tropical north Atlantic ocean during August 1989, J. Geophys. Res., 99, 22513-22523, 1994.

OSD

7, 1953-1976, 2010

Water masses and zonal current in the

Western Tropical

Atlantic

A. C. Silva et al.

Title Page

Abstract

Introduction

Conclusions

References

Tables

Figures

14

4

Back

Close

Full Screen / Esc

Printer-friendly Version

Interactive Discussion 


\section{OSD}

7, 1953-1976, 2010

Water masses and zonal current in the

Western Tropical Atlantic cruises.

\begin{tabular}{lcccccc}
\hline $\begin{array}{l}\text { Water } \\
\text { Masses }\end{array}$ & $\begin{array}{c}\text { Depth } \\
(\mathrm{m})\end{array}$ & $\begin{array}{c}\text { Potential } \\
\text { temp. } \\
\left({ }^{\circ} \mathrm{C}\right)\end{array}$ & Salinity & $\begin{array}{c}\text { Oxygen } \\
\text { Dissolved } \\
\left(\mu \mathrm{mol} \mathrm{kg}{ }^{-1}\right)\end{array}$ & $\begin{array}{c}\text { Potential } \\
\text { Density } \sigma_{\theta}\end{array}$ & $\begin{array}{c}\mathrm{AOU} \\
\left(\mu \mathrm{mol} \mathrm{kg}^{-1}\right)\end{array}$ \\
\hline Amazon fresh waters & $\begin{array}{c}\text { Surface } \\
\text { SMW }\end{array}$ & 29.4 & 25.9 & 205.6 & 15.1 & 0 \\
NACW & 93 & 23.0 & 36.9 & 156.0 & 25.3 & 53.0 \\
SACW & 163 & 13.9 & 35.65 & 109.2 & 26.7 & 142.8 \\
ACW & 225 & 11.9 & 35.1 & 164.8 & 26.7 & 98.9 \\
Water Mass Mixture & 680 & 6.55 & 34.62 & 123.94 & 27.18 & 174.2 \\
AAIW-Guyane & 795 & 5.09 & 34.56 & 140.0 & 27.3 & 170.0 \\
UNADW & 700 & 5.56 & 34.58 & 134.60 & 27.28 & 171 \\
MNADW & 1630 & 4.28 & 35.0 & 234.69 & 27.76 & 79.4 \\
LNADW & 1980 & 3.43 & 34.97 & 254.5 & 27.8 & 66.3 \\
\hline
\end{tabular}

A. C. Silva et al.

Title Page

Abstract

Introduction

Conclusions

References

Tables

Figures

14

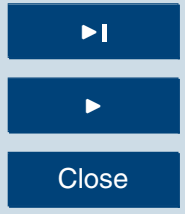

Back

Close

Full Screen / Esc

Printer-friendly Version

Interactive Discussion 

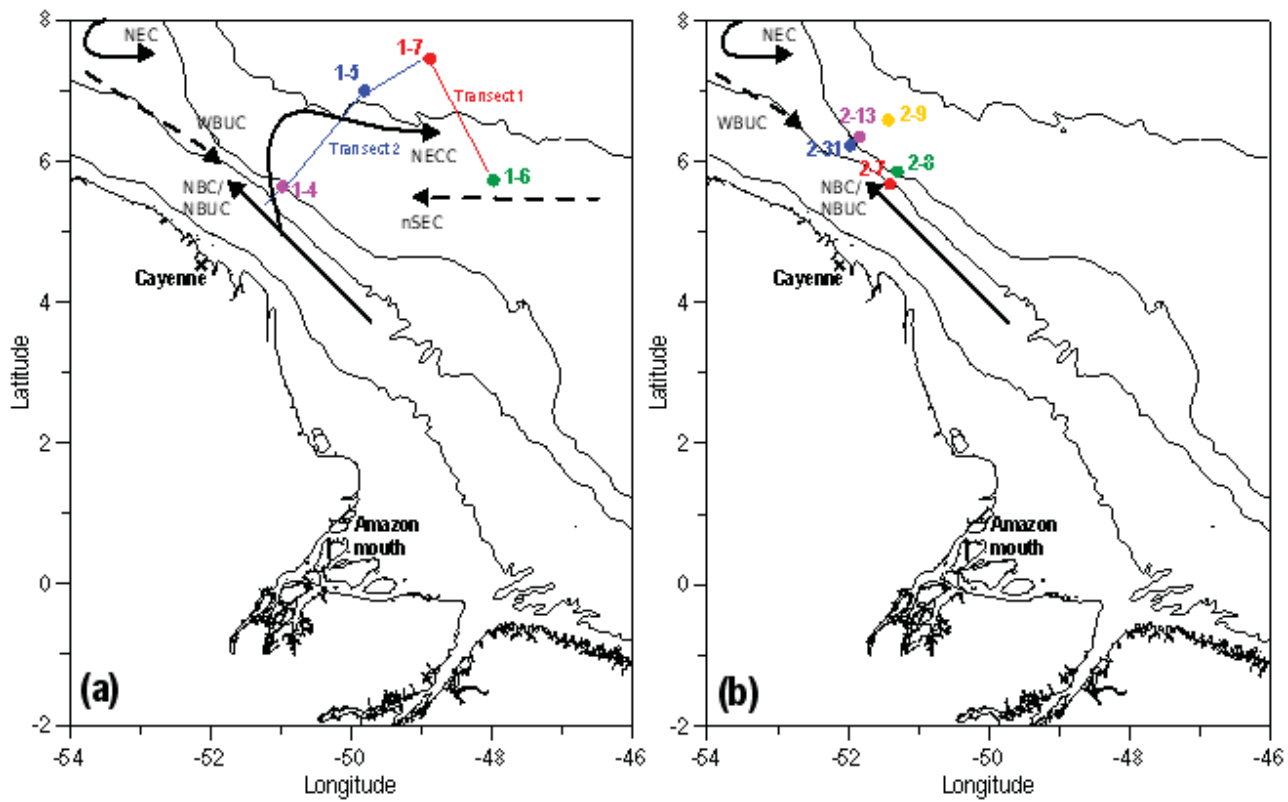

OSD

7, 1953-1976, 2010

Water masses and zonal current in the

Western Tropical

Atlantic

A. C. Silva et al.

Title Page

Abstract

Conclusions

Tables

14

4

Back

Introduction

References

Figures

Fig. 1. Maps of the two cruises considered in this study: (a) October 2007 - AMANDES 1, (b) January 2008 - AMANDES 2. The track lines (Transects 1 and 2) indicate the location of the coverage for acoustic Doppler current profiler (ADCP) and circles represent conductivitytemperature-depth- $\mathrm{O}_{2}\left(\mathrm{CTDO}_{2}\right)$ profiles stations. Schematic diagram of the surface currents (NBC - North Brazil Current; NECC - North Equatorial Counter-current) and subsurface current (NBUC - North Brazil Undercurrent; WBUC - Western Boundary Undercurrent; nSEC - north South Equatorial Current). The 20-, 200-, 2000- and 4000-m isobaths are shown.

\section{Full Screen / Esc}

Printer-friendly Version

Interactive Discussion 


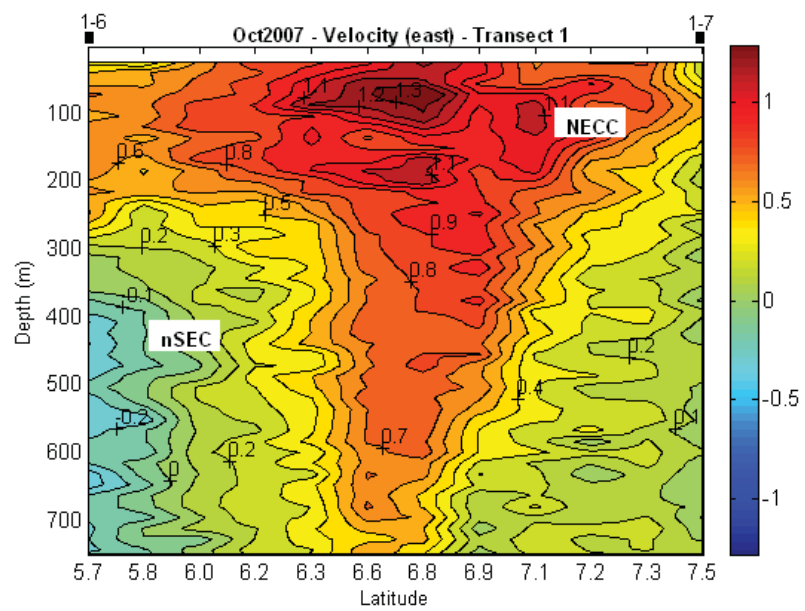

OSD

7, 1953-1976, 2010

\section{Water masses and zonal current in the \\ Western Tropical Atlantic}

A. C. Silva et al.

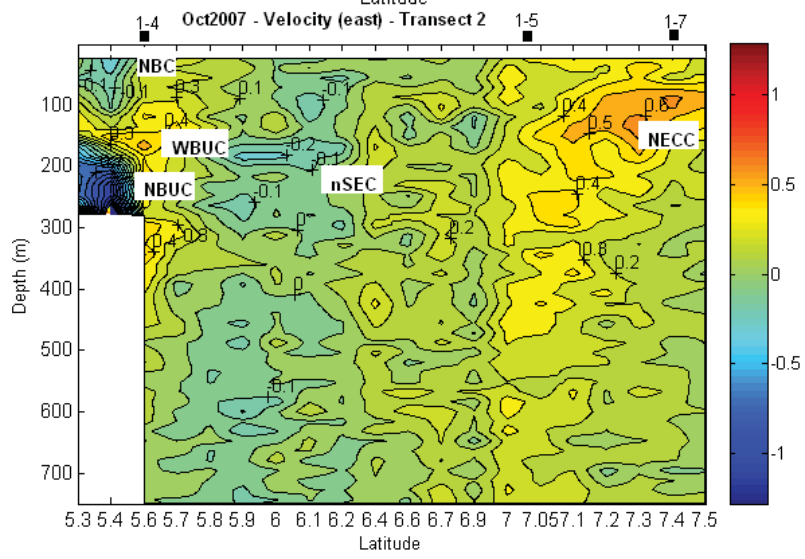

Title Page

Abstract

Introduction

Conclusions

References

Tables

Figures

\section{4}

4

Back

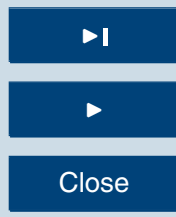

Full Screen / Esc

Fig. 2. Vertical sections of eastward velocity component (in meter per second) along two transects - Transect 1 (a) and Transect 2. The latitude reported on the X-axis corresponds to the locations of the ADCP velocity measurements in the studied area (see Fig. 1). CTDO 2 station positions are indicated at the top of each panel. 

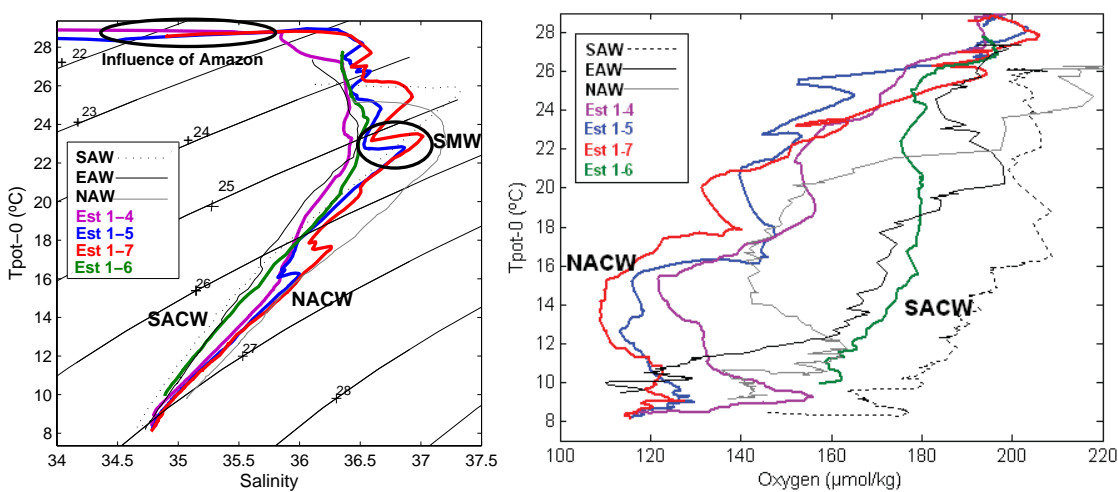

OSD

7, 1953-1976, 2010

Water masses and zonal current in the

Western Tropical Atlantic

A. C. Silva et al.
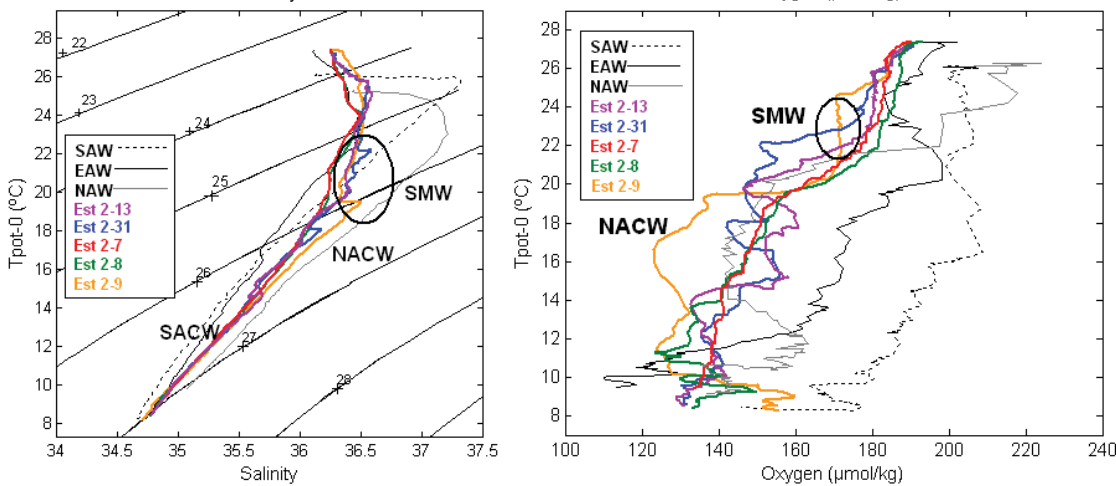

Title Page

Abstract

Introduction

Conclusions

References

Tables

Figures

Fig. 3. (a) $\theta$-S diagrams and (b) $\theta-\mathrm{O}_{2}$ plotted Surface water layer $(<400 \mathrm{~m})$ derived from the conductivity-temperature-depth- $\mathrm{O}_{2}\left(\mathrm{CTDO}_{2}\right)$ profiles stations during October 2007 and (c) $\theta$-S diagrams and (d) $\theta-\mathrm{O}_{2}$ plotted Surface water layer derived from $\mathrm{CTDO}_{2}$ profiles stations during January 2008. Yellow, blue, red, green and black lines represent the profiles of the stations identified with the same colours in Fig. 1. In all figures the bold lines are used to define typical $\theta-S$ and $\theta-\mathrm{O}_{2}$ features of the North Atlantic Water (NAW), South Atlantic Water (SAW) and Eastern Atlantic Water (EAW).

\section{4}

4

Back

Full Screen / Esc

Printer-friendly Version

Interactive Discussion 

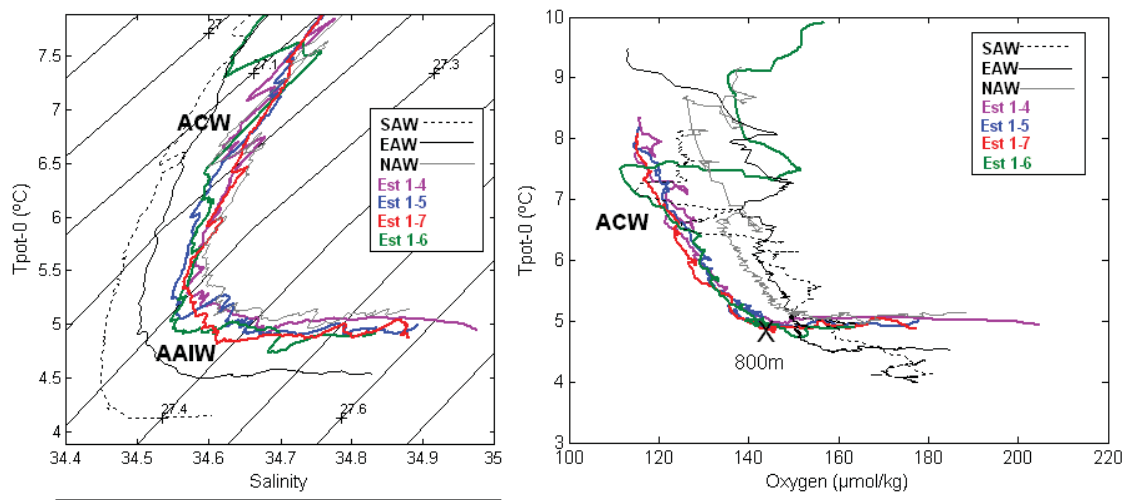

OSD

7, 1953-1976, 2010

Water masses and zonal current in the

Western Tropical Atlantic

A. C. Silva et al.
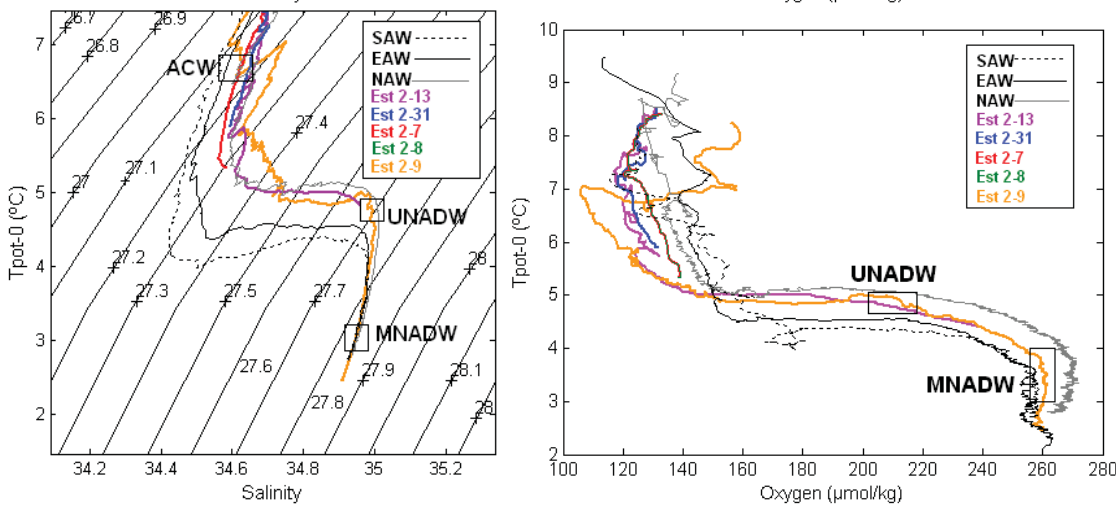

Title Page

Abstract

Introduction

Conclusions

References

Tables

Figures

Fig. 4. (a) $\theta$-S diagrams and (b) $\theta-\mathrm{O}_{2}$ plotted intermediate water layer $(400-1200 \mathrm{~m})$ derived from the conductivity-temperature-depth- $\mathrm{O}_{2}\left(\mathrm{CTDO}_{2}\right)$ profiles stations during October 2007; and (c) $\theta$-S diagrams and (d) $\theta-\mathrm{O}_{2}$ plotted intermediate and deep water layer derived from the $\mathrm{CTDO}_{2}$ profiles stations during January 2008 (see circles in Fig. 1).

\section{4}

4

Back

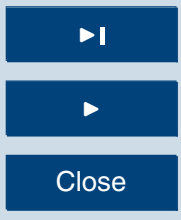

Full Screen / Esc

Printer-friendly Version

Interactive Discussion 

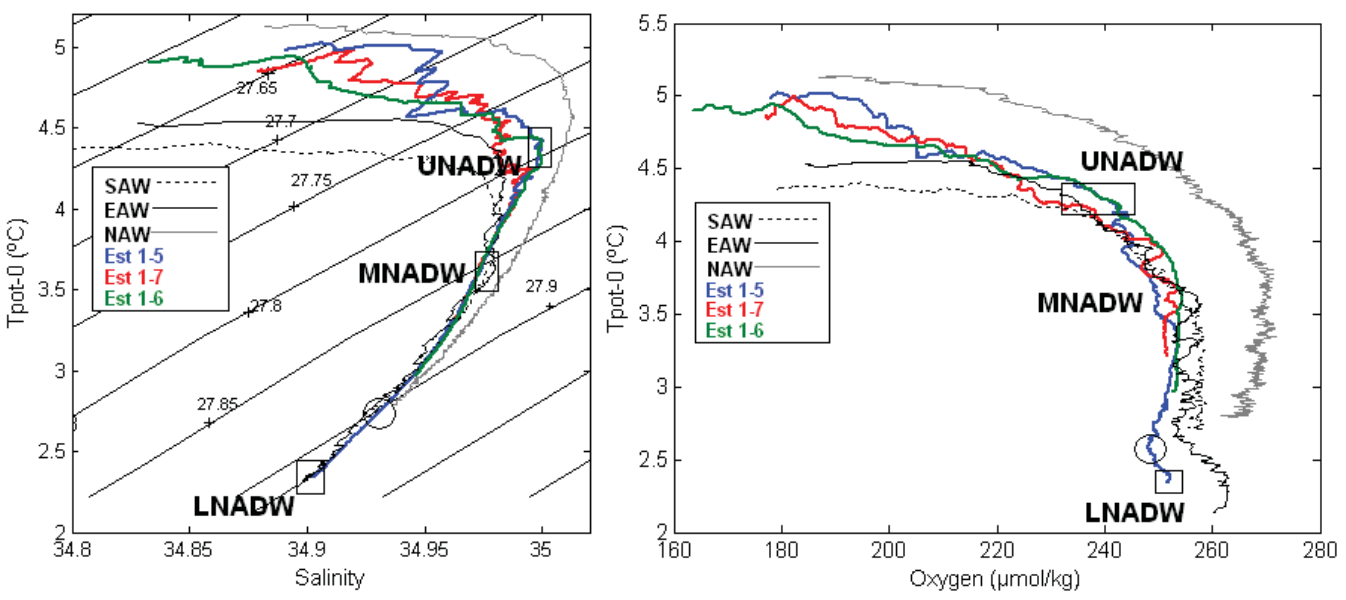

Fig. 5. (a) $\theta$-S diagrams and (b) $\theta-\mathrm{O}_{2}$ plotted deep water layer $(1200-4000 \mathrm{~m}$ ) derived from the conductivity-temperature-depth- $\mathrm{O}_{2}\left(\mathrm{CTDO}_{2}\right)$ profiles stations during January 2008 (see circles in Fig. 1).
OSD

7, 1953-1976, 2010

Water masses and zonal current in the

Western Tropical

Atlantic

A. C. Silva et al.

Title Page

Abstract

Introduction

Conclusions

References

Tables

Figures

14

$\rightarrow 1$

4

Back

Close

Full Screen / Esc

Printer-friendly Version

Interactive Discussion 


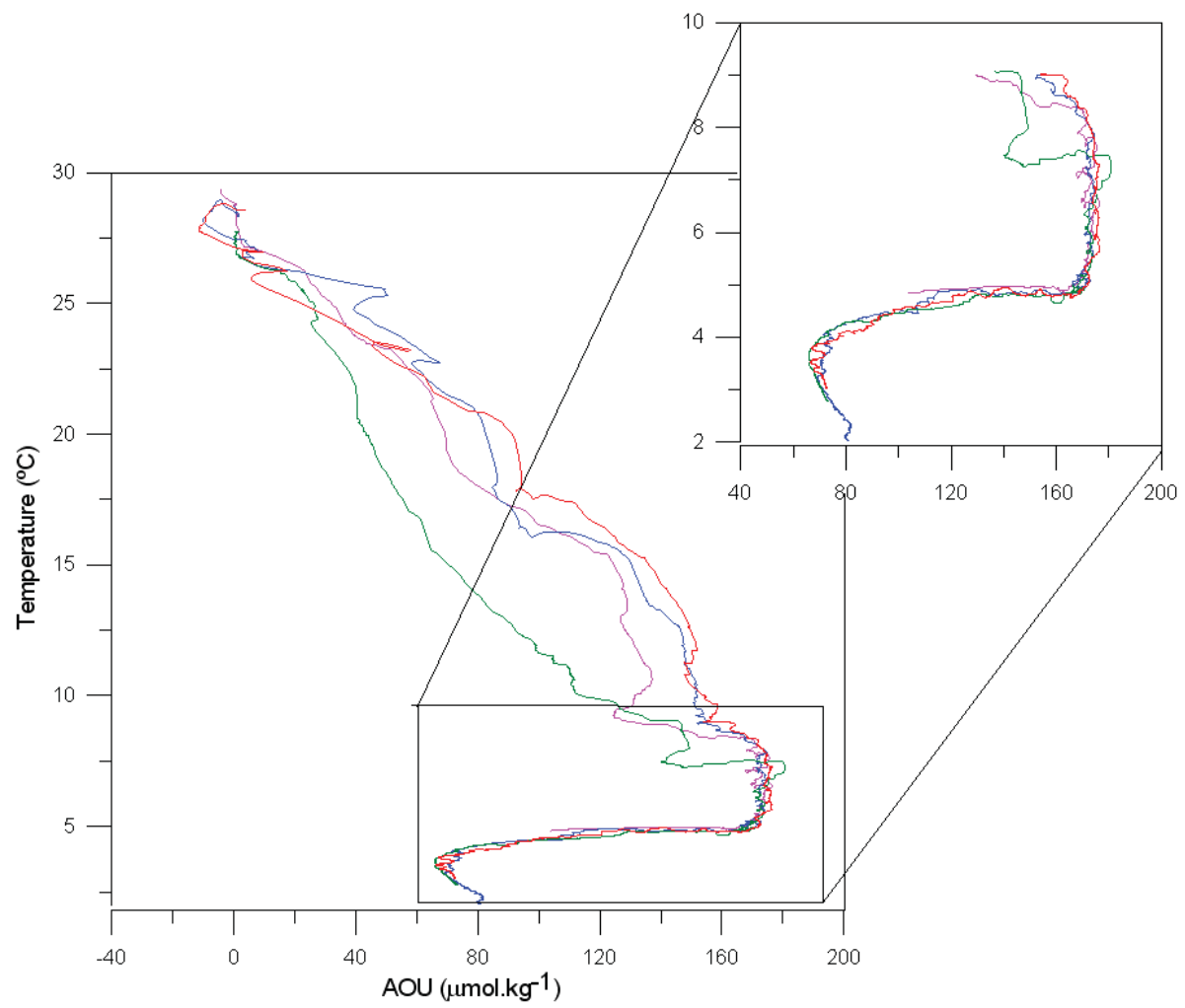

Fig. 6. Profil of the Apparent Oxygen Utilization parameter (AOU) versus temperature $\left({ }^{\circ} \mathrm{C}\right)$.
OSD

7, 1953-1976, 2010

Water masses and zonal current in the

Western Tropical Atlantic

A. C. Silva et al.

Title Page

Abstract

Introduction

Conclusions

References

Tables

Figures

14

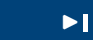

4

Back

Close

Full Screen / Esc

Printer-friendly Version

Interactive Discussion 
OSD

7, 1953-1976, 2010

Water masses and zonal current in the

Western Tropical Atlantic

A. C. Silva et al.

\section{Title Page}

Abstract

Introduction

Conclusions

References
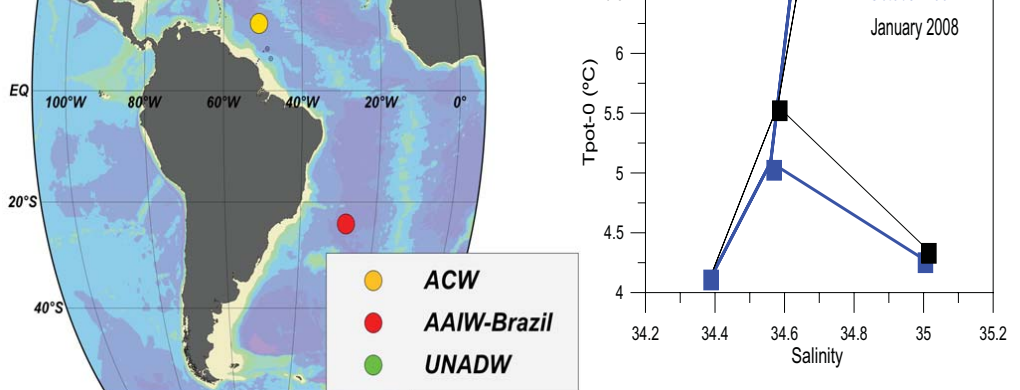

39,8\% NACW

$46,6 \%$ AAIW

Jan. 2008

$587 \%$ NACW

$33,6 \%$ AAIW

$7,6 \%$ UNADW

\section{Tables}

Figures

14

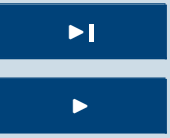

Back

Close

Full Screen / Esc

Fig. 7. Evolution of the water masses composition (mixture and oxygen consumption) during the AMANDES cruises.

Printer-friendly Version

Interactive Discussion 